Published in final edited form as:

Tetrahedron Lett. 2018 December 19; 59(51): 4521-4524. doi:10.1016/j.tetlet.2018.11.034.

\title{
Synthesis of $9-\mathrm{CD}_{3}-9$-cis-Retinal Cofactor of Isorhodopsin
}

\author{
Mozhgan Navidia $^{a}$, Shreya Yadava ${ }^{a}$ Andrey V. Struts ${ }^{b}$ Michael F. Brown $^{b}$, and Nasri Nesnas ${ }^{a}$ \\ aDepartment of Biomedical \& Chemical Engineering \& Sciences, Florida Institute of Technology, \\ Melbourne, Florida 32901, USA

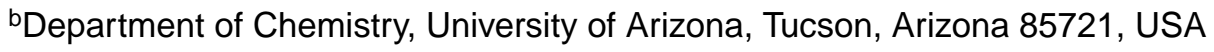

\begin{abstract}
We report the synthesis of $9-\mathrm{CD}_{3}-9$-cis-retinal via a six-step procedure from $\beta$-ionone. The steps involve an initial deuteration of the methyl ketone of $\beta$-ionone followed by two consecutive Horner-Wadsworth-Emmons (HWE) coupling reactions and their corresponding DIBAL reductions. A final oxidation of the allylic alcohol of the retinol leads to the target compound. This deuterium labeled retinoid is an important cofactor for studying protein-retinoid interactions in isorhodopsin.
\end{abstract}

\section{Graphical Abstract:}<smiles>CC(=O)/C=C/C1=C(C)CCCC1(C)C</smiles><smiles></smiles>
$8.2 \%$ overall yield

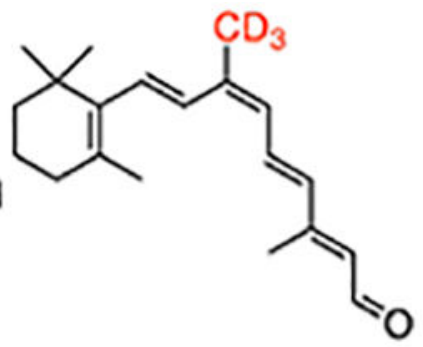

\section{Keywords}

Retinoids; 9- $\mathrm{CD}_{3}$-9-cis-retinal; isorhodopsin; labeled retinal; rhodopsin

\section{Introduction}

Retinoids are a group of natural and synthetic analogues of vitamin A with critical roles in various biological processes including vision, cell differentiation, immune responses, reproduction, and brain functions. ${ }^{1-5}$ The chromophore for the visual pigment, rhodopsin, is

Publisher's Disclaimer: This is a PDF file of an unedited manuscript that has been accepted for publication. As a service to our customers we are providing this early version of the manuscript. The manuscript will undergo copyediting, typesetting, and review of the resulting proof before it is published in its final citable form. Please note that during the production process errors may be discovered which could affect the content, and all legal disclaimers that apply to the journal pertain.

A. Supplementary data

Supplementary data (experimental procedures, characterization data, and ${ }^{1} \mathrm{H}$ and ${ }^{13} \mathrm{C}$ NMR spectra) associated with this article can be found in the online version, at https://doi.org/... 
11-cis-retinal. Isomerization of 11-cis-retinal to all-trans-retinal initiates the visual signal transduction pathway. ${ }^{6}$ During the last decades, many researchers have aimed to uncover the details of the intricate steps of the visual cycle through preparation of 11-cis-retinal and a wide variety of its analogues. ${ }^{7}$ These analogues have been used to assess the critical components of the chromophore and their effect on spectral sensitivities and function of rhodopsin. ${ }^{5}$ Examples of some of these analogues include: demethylated and methyl switched retinoids, haloretinoids, arotinoids, conformationally locked retinoids, and retinoid isotopomers. ${ }^{8-14}$

An especially interesting analogue of the native chromophore 11-cis-retinal (1) is 9-cisretinal (2), which can also bind to opsin via the Schiff base with Lys296 forming isorhodopsin (Figure 1). Here we present the previously unreported organic synthesis of the deuterated analogue at $\mathrm{C}$, which is 9- $\mathrm{CD}_{3}-9$-cis-retinal. Rhodopsin and isorhodopsin go through a similar bleaching sequence; ${ }^{15}$ however, isorhodopsin undergoes a slower and less efficient bleaching, and this is significant, as it would facilitate its photophysical studies. Furthermore, 9-cis-retinal shows distinct spectral properties in comparison to 11-cis-retinal, which makes it an interesting candidate for the study of vision. As such, having a facile synthesis for 9-cis-retinal becomes of great value. Earlier reports of organic synthesis of 9cis-retinal are scarce, and the compound was only reported in passing as a by-product from other pathways, or in a mixture of photoisomerized products of all-trans-retinal. For example, Duhamel and coworkers published two papers in 1987 on retinal preparation. ${ }^{16,17}$ They mentioned 9-cis-retinal as one of the retinoids formed through their synthesis. In 2003, Sashima et al. reported that irradiation of all-trans-retinal could lead to several of its isomers, including 9-cis-retinal which was separated through HPLC. ${ }^{18}$ More recent reports are mostly focused on 9-cis-retinoic acid and 9-cisretinoic ester, and occasionally 9-cis-retinal derivatives, examples of which are shown in Figure 2 (compounds 3-6). ${ }^{8,19-22}$ While 9-cisretinal is now commercially available, at relatively high prices, it is useful to present an efficient pathway for its synthesis to enable isotopic labeling and for others to design pertinent analogues. Due to the similarities between rhodopsin and isorhodopsin, and to further study the importance of this methyl group, we have synthesized $9-\mathrm{CD}_{3}-9$-cis-retinal. One goal is to use solid-state NMR spectroscopy to investigate the structure and dynamics of 9-cis-retinal in the isorhodopsin binding pocket. ${ }^{23,24}$ Isotopically labeled retinoids are also useful in studies employing neutron diffraction ${ }^{25-27}$ and vibrational spectroscopy. ${ }^{28,29}$ To our knowledge, this is the first report on the preparation of this labeled molecule.

\section{Results and discussion}

Our synthesis began with the commercially available $\beta$-ionone 7 which was almost quantitatively converted to its deuterated form, labeled $\beta$-ionone $\mathbf{8}$, using previously reported methods with greener modifications that avoided the use of pyridine. ${ }^{30}$ Compound $\mathbf{8}$ was then treated with diethyl (cyanomethyl) phosphonate 9 to afford a mixture of a 2:1 $E / Z$ isomers, as determined by NMR, of $\mathbf{1 0}$ in $89 \%$ yield (Scheme 1 ). The $E / Z$ mixture cannot be separated at that stage, and was therefore subjected to reduction as a mixture. One of the challenges in isotope labeling is designing the reaction conditions in a way that minimizes the possibility of H/D exchange. Our earlier attempts to synthesize 10, using sodium hydride as base instead of $n-\mathrm{BuLi}$, resulted in some loss of the D-label as observed by NMR and 
DART-MS. This problem was solved by replacing $\mathrm{NaH}$ with $n$-BuLi. It is likely that the intimate ion pair in carbanion 13 (Figure 3), when $\mathrm{M}=\mathrm{Li}$, possesses lower basicity than when $\mathrm{M}=\mathrm{Na}$, and is therefore not sufficiently basic to exchange the a-deuterium of $\mathbf{8}$. Attempts to increase $Z$ selectivity for this step via other phosphonates or bases were not successful. These attempts either led to higher $Z$ selectivity, with much lower yields, or resulted in undesirable H/D exchange. A summary of the optimization for this HWE step can be found in Table S1 (see Supporting Information).

Reduction of $\mathbf{1 0}$ using diisobutylaluminum hydride (DIBAL) in dichloromethane (DCM) solvent, resulted in the expected 2:1 ratio of $E / Z$ isomers. The desired $Z$ aldehyde $\mathbf{1 1}$ was separated (25\%) through column chromatography from the overall mixture (76\%) of the two diastereomers (Scheme 1). It should be noted that aldehyde $\mathbf{1 2}$ is indeed a useful intermediate and precursor for synthesis of the all-trans labeled retinal. It was then used for the formation of $\mathrm{C} 11=\mathrm{C} 12$ bond according to the procedure reported by Bennani, using phosphonate 14, $n$-butyllithium and 1,3-dimethyltetrahydropyrimidin-2(1H)-one (DMPU) in THF (Scheme 2) ${ }^{31}$ Ester 15 formed through this method (83\%) mostly contained the desired $E$ product ( $E / Z$ ratio of 17:1 based on NMR). Separation of the stereoisomers was not feasible at that step; therefore, reduction to the alcohol was performed using the isomeric mixture in hand. Because alcohol $\mathbf{1 6}$ is not very stable, it was obtained in sufficient purity simply after extraction of the crude, and was used in the last step without further purification. Oxidation of $\mathbf{1 6}$ was achieved using commercially activated $\mathrm{MnO}_{2}$. The 9$\mathrm{CD}_{3}$-9-cis-retinal, product 17 , was obtained as a yellow solid after purification by column chromatography (49\%). The ratio of the formed diastereomers was in favor of the desired $E$ isomer ( $E / Z: 12: 1$ based on isolated yields). Replacing the last step with an alternative published oxidation condition using $\mathrm{MnO}_{2}$ at room temperature ${ }^{32}$ afforded similar yield of the target aldehyde. The structure of the labeled retinal was fully characterized using IR, UV, ${ }^{1} \mathrm{H}$ NMR, ${ }^{13} \mathrm{C}$ NMR, and DART-MS (see Supplementary Data). The electronic UV spectrum of 9- $\mathrm{CD}_{3}$-9-cis-retinal (this work) is compared to authentic 9-cis-retinal and all-trans-retinal UV spectra in Figure 4. For these retinoids $n$-hexanes solutions with a concentration of $1.7 \times$ $10^{-3} \mathrm{M}$ were prepared and studied at room temperature. The synthesized labeled retinal 17 and the commercially available 9 -cis-retinal had identical $\lambda_{\max }$ at $366 \mathrm{~nm}$, as expected. Alltrans-retinal showed a slight red shift and gave an observed $\lambda_{\max }$ at $370 \mathrm{~nm}$. The similarity between the $\lambda_{\max }$ of the synthesized molecule and the authentic commercial 9-cis-retinal added confidence to our confirmed stereochemistry of the reported $9-\mathrm{CD}_{3}-9$-cis-retinal.

Isotope labeling is a commonly used technique to track changes as they occur in biological processes. A major advantage of isotopic labeling is the fact that the labeled molecules are sterically and electronically identical in properties to their native analogues. There are many reports available on using deuterium and carbon- 13 enriched retinoids for investigating different aspects of the visual cycle, with the help of spectroscopic methods such as solidstate magic-angle-spinning NMR, Raman, or FTIR. ${ }^{32-35}$ Studies have shown that the nonbonding interactions of the methyl group on $\mathrm{C} 9$ of 11-cis-retinal with opsin is necessary for rhodopsin activation. ${ }^{11,36}$ Our synthesis of the $9-\mathrm{CD}_{3}-9$-cis-retinal gives a new route to testing structure-function hypotheses for visual rhodopsin and other retinal proteins. Research indicates the C9-methyl group of retinal in the 11-cis (dark state of rhodopsin) and 
all-trans (active metarhodopsin-II state) conformations is a dynamical hot spot of the chromophore, ${ }^{37,38}$ due to weak nonbonded interactions with surrounding amino acids of the binding pocket. As for intra-retinal interactions of the C9-methyl group, they are reduced by its approximately symmetric position with respect to the adjacent polyene. ${ }^{37-40}$ For 11 -cisretinal the $(1,6)$ interactions of the $\mathrm{C} 9$-methyl hydrogens with the $7 \mathrm{H}$ and $11 \mathrm{H}$ atoms of the adjacent $\mathrm{C} 7=\mathrm{C} 8$ and $\mathrm{C} 11=\mathrm{C} 12$ double bonds give a flattened potential energy surface with a smaller activation barrier. ${ }^{37,39}$ In 9-cis-retinal the $(1,6)$ interaction involving the C11=C12 double bond is replaced by a $(1,5)$ interaction with the $(e) \mathrm{H}$ of the same double bond. Solidstate ${ }^{2} \mathrm{H}$ NMR studies of $9-\mathrm{CD}_{3}-9$-cis-retinal bound to rhodopsin can explore the potential energy surface in the electronic ground state, and the changes that occur due to photon absoprtion. ${ }^{41}$ Additional structural studies, e.g., using solid-state NMR and vibrational spectroscopy, can reveal the specific ligand geometry, and activating changes due to interactions with the receptor binding pocket. ${ }^{41}$

\section{Conclusion}

In summary, we report the synthesis of $9-\mathrm{CD}_{3}-9$-cis-retinal. This route is efficient in that the desired stereoisomers were the major diastereomers formed in the reactions, except for the aldehyde 11 where the minor $Z$ isomer had to be isolated, and the $E$ isomer kept for the synthesis of the all-trans labeled retinoid. Furthermore, the isotopomer composition of the molecule remained intact following the labeling step. Notably two of the six steps (formation of compounds $\mathbf{8}$ and 16) did not require any purification through column chromatography. Investigation of the dynamics of 9- $\mathrm{CD}_{3}-9$-cis-retinal, also referred to as 9$Z$-[9-C $\left.{ }^{2} \mathrm{H}_{3}\right]$-retinal, bound to isorhodopsin is in progress and will be reported in due course.

\section{Supplementary Material}

Refer to Web version on PubMed Central for supplementary material.

\section{Acknowledgments}

This research was funded in part by the US NIH (R15 GM112119 to N.N., R01 EY026041 and R01 EY012049 to M.F.B.), and by the NSF (MCB 1817862 to M.F.B.). A.V.S. was supported by the Russian Foundation for Basic Research (16-04-00494A).

\section{References}

1. Thompson DA, Janecke AR, Lange J, Feathers KL, Hübner CA, McHenry CL, Stockton DW, Rammesmayer G, Lupski JR, Antinolo G, Ayuso C, Baiget M, Gouras P, Heckenlively JR, den Hollander A, Jacobson SG, Lewis RA, Sieving PA, Wissinger B, Yzer S, Zrenner E, Utermann G, Gal A. Hum Mol Gen. 2005; 14: 3865-3875. [PubMed: 16269441]

2. Di Masi A, Leboffe L, De Marinis E, Pagano F, Cicconi L, Rochette-Egly C, Lo-Coco F, Ascenzi P, Nervi C. Mol Aspec Med. 2015; 41: 1-115.

3. Gearhart PM, Gearhart C, Thompson DA, Petersen-Jones SM. Arch Ophthalmol. 2010; 128: 14421448. [PubMed: 20837787]

4. Álvarez R, Vaz B, Gronemeyer H, De Lera RA. Chem Rev. 2014; 114: 1-125. [PubMed: 24266866]

5. Kiser PD, Golczak M, Palczewski K. Chem Rev. 2014; 114: 194-232. [PubMed: 23905688]

6. Fishkin N, Berova N, Nakanishi K. Chem Rec. 2004; 4: 120-135. [PubMed: 15073879]

7. Nakanishi K, Crouch K. Isr J Chem. 1995; 35: 253-272. 
8. Alvarez R, Domínguez M, Pazos Y, Sussman F, De Lera AR. Chem-A Eur J. 2003; 9: 5821-5831.

9. Vogel R, Siebert F, Lu S, Reho V, May RV, Re V, Recei M, June V. Biochemistry. 2005; 44: 11684 11699. [PubMed: 16128569]

10. Zhang H, Lerro KA, Yamamoto T, Hung Lien T, Sastry L, Nakanishi K, Gawinowicz MA. J Am Chem Soc. 1994; 116: 10165-10173.

11. Domínguez M, Álvarez R, Pérez M, Palczewski K, De Lera AR. ChemBioChem. 2006; 7: 18151825. [PubMed: 16941510]

12. Nesnas N, Rando RR, Nakanishi K. Tetrahedron. 2002; 58: 6577-6584.

13. Borhan B, Souto ML, Um JM, Zhou B, Nakanishi K. Chem - A Eur J. 1999: 1172-1175.

14. Matsuda H, Zhang S, Holmes AE, Krane S, Itagaki Y, Nakanishi K, Nesnas N. Can J Chem. 2006; 84: $1363-1370$.

15. Schoenlein RW, Peteanu LA, Wang Q, Mathies RA, Shank CV. J Phys Chem. 1993; 97: 1208712092.

16. Duhamel L, Duhamel P, Lecouvé JP. Tetrahedron. 1987; 43: 4349-4358.

17. Duhamel L, Duhamel P, Lecouvé JP. Tetrahedron. 1987; 43: 4339-4348.

18. Sashima T, Hashimoto H, Koshihara S. Chem Phys Lett. 2003; 369: 380-385.

19. Maj J, Morzycki JW, Rárová L, Wasilewski G, Wojtkielewicz A. Tetrahedron Lett. 2012; 53: 54305433.

20. Okitsu T, Iwatsuka K, Wada A. Chem Commun. 2008: 6330.

21. Ok H, Caldwell C, Schroeder DR, Singh AK, Nakanishi K. Tetrahedron Lett. 1988; 29: 22752278.

22. Wang Y, Lugtenburg J. Eur J Org Chem. 2004: 3497-3510.

23. Struts AV, Brown MF. In Advances in Biological Solid-State NMR: Proteins and Membrane-Active Peptidese; Separovic F, and Naito A, Eds.; The Royal Society of Chemistry, 2014; pp 320-352.

24. Brown MF, Heyn MP, Job C, Kim S, Moltke S, Nakanishi K, Nevzorov AA, Struts AV, Salgado GFJ, Wallat I. Biochim Biophys Acta. 2007; 1768: 2979-3000. [PubMed: 18021739]

25. Hauss T, Grzesiek S, Otto H, Westerhausen J, Heyn MP. Biochemistry. 1990; 29: 4904-4913. [PubMed: 2364067]

26. Heyn MP, Westerhausen J, Wallat I, Seiff F. Proc Natl Acad Sci U S A. 1988; 85: 2146-2150. [PubMed: 16593918]

27. Seiff F, Westerhausen J, Wallat I, Heyn MP. Proc Natl Acad Sci U S A. 1986; 83: 7746-7750. [PubMed: 16593768]

28. Schnedermann C, Yang X, Liebel M, Spillane KM, Lugtenburg J, Fernández I, Valentini A, Schapiro I, Olivucci M, Kukura P, Mathies RA. Nat. Chem 2018; 10: 449-455. [PubMed] [PubMed: 29556051]

29. Kukura P, McCamant DW, Yoon S, Wandschneider DB, Mathies RA. Science. 2005; 310: 10061009. [PubMed: 16284176]

30. Johansen JE, Liaaen-Jensen S. Acta Chem Scand. 1974; 28B: 349-356.

31. Bennani YL. J Org Chem. 1996; 61: 3542-3544.

32. Bergueiro J, Montenegro J, Saá C, López S. Chem - A Eur J. 2012;18: 14100-14107.

33. Dawadi PBS, Lugtenburg J. Molecules. 2010; 15: 1825-1872. [PubMed: 20336016]

34. Tanaka K, Struts AV, Krane S, Fujioka N, Salgado GFJ, Martínez-Mayorga K, Brown MF, Nakanishi K. Bull Chem Soc Jpn. 2007; 80: 2177-2184.

35. Creemers AFL, Lugtenburg J. J Am Chem Soc. 2002; 124: 6324-6334. [PubMed: 12033861]

36. Torrado A, Iglesias B, López S, de Lera AR. Tetrahedron. 1995; 51: 2435-2454.

37. Struts AV, Salgado GFJ, Martínez-Mayorga K, Brown MF. Nat Struct Mol Biol. 2011; 18: 392394. [PubMed: 21278756]

38. Struts AV, Salgado GFJ, Brown MF. Proc Natl Acad Sci. 2011; 108: 8263-8268. [PubMed: 21527723]

39. Mertz B, Lu M, Brown MF, Feller SE. Biophys J. 2011; 101: L17-L19. [PubMed: 21806916]

40. Mertz B, Struts AV, Feller SE, Brown MF. Biochim Biophys Acta. 2012; 1818: 241-251. [PubMed: 21851809]

Tetrahedron Lett. Author manuscript; available in PMC 2019 December 19. 
41. Struts AV, Salgado GFJ, Tanaka K, Krane S, Nakanishi K, Brown MF. J Mol Biol. 2007; 372: 5066. [PubMed: 17640664] 


\section{Highlights}

- $\quad$ Deuterium labeled 9Z retinoid synthesized in 6 steps

- 2 Steps require no purification

- Efficient greener introduction of a deuterium label in the first step

- Negligent loss of the deuterium label 


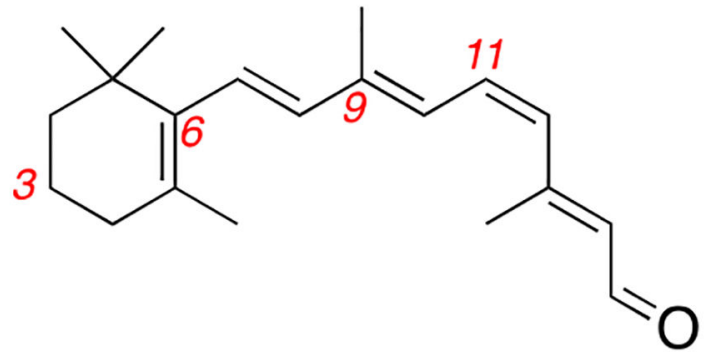

\section{1-cis-Retinal (1)}

Figure 1.

Structures of 11-cis-retinal and 9-cis-retinal.

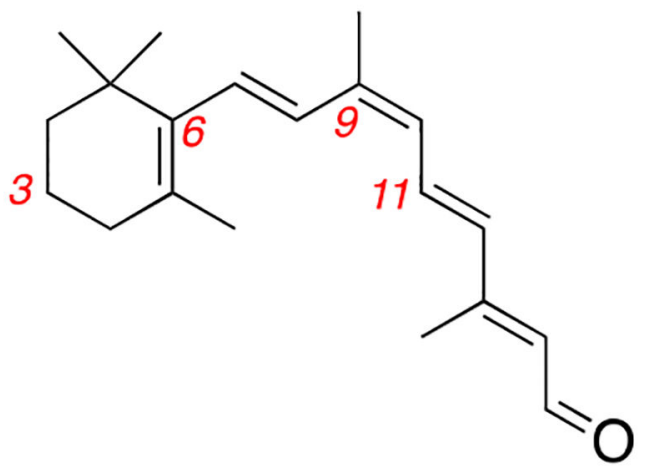

9-cis-Retinal (2) 


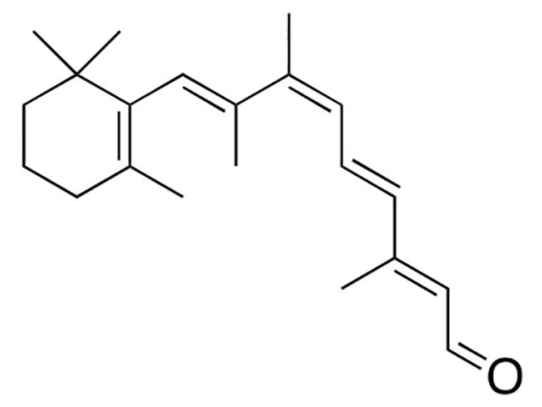

8-Methyl-9-cis-retinal (3)<smiles>CC1=C(/C=C/C(C)=C\C=C\C(C)=C\C(=O)O)C(C)(C)CCC1</smiles>

9-cis-Retinoic acid (5)

Figure 2.

Examples of reported retinoids.

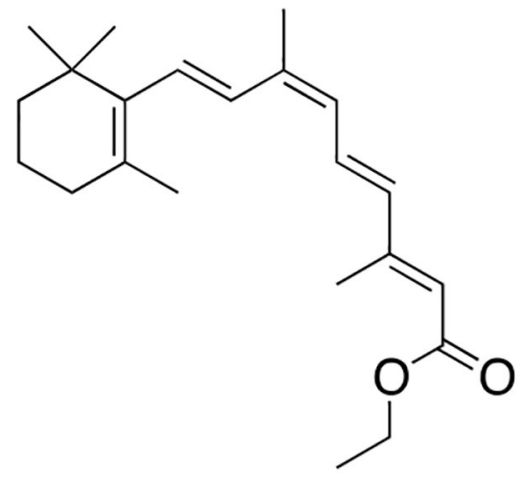

9-cis-Ethylretinoate (4)<smiles>CC1=C(/C=C/C(C)=C\C=C\C(C)=C\C=O)C(C)(C)C[C@H](O)C1</smiles>

3S-Hydroxy-9-cis-retinal (6) 


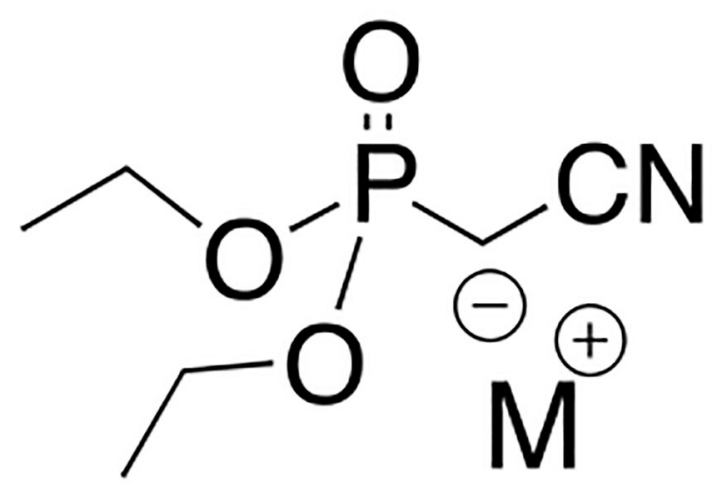

$\mathrm{M}=\mathrm{Li}, \mathrm{Na}$

\section{3}

Figure 3.

Carbanion formed in Horner-Wadsworth-Emmons reaction. 


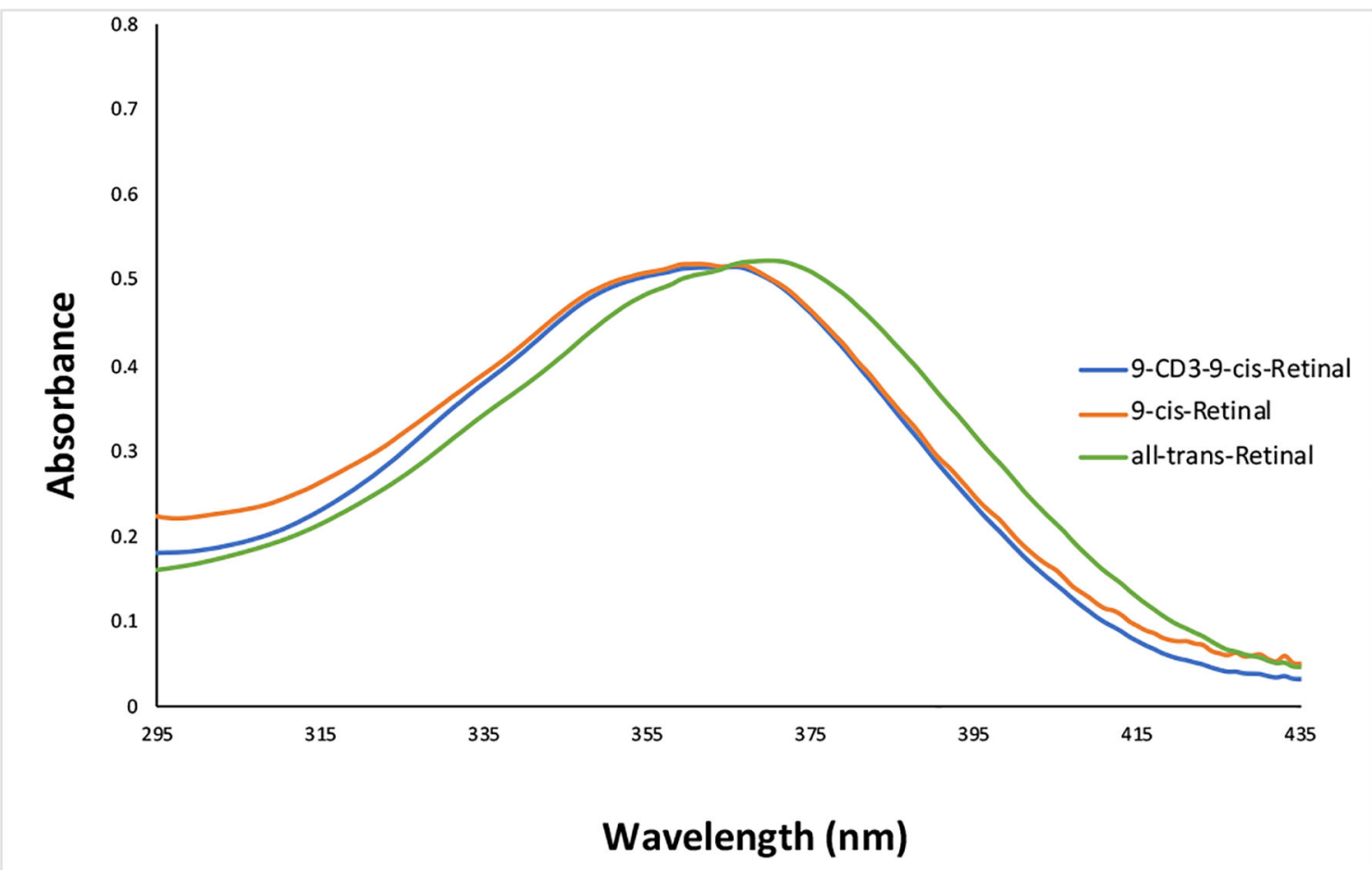

Figure 4.

Electronic UV spectra of synthesized 9- $\mathrm{CD}_{3}-9$-cis-retinal (blue), commercial 9-cis-retinal (red), and commercial alltrans-retinal (green). Solutions contained $1.7 \times 10^{-3} \mathrm{M}$ retinoids in $n$-hexane at room temperature. The absorption maximum $\left(\lambda_{\max }\right)$ obtained for $9-\mathrm{CD}_{3}-9-$ cisretinal and 9-cis-retinal was $366 \mathrm{~nm}$; while for all-trans-retinal $\lambda_{\max }$ it was at $370 \mathrm{~nm}$. 
<smiles>CC(=O)/C=C/C1=C(C)CCCC1(C)C</smiles>

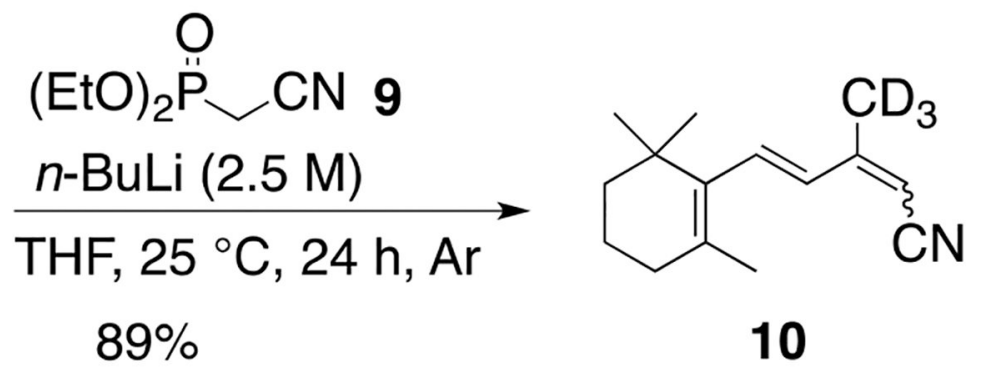

$E / Z: 2: 1$

DIBAL (2.5 equiv, $1 \mathrm{M}$ in heptane)<smiles></smiles>
$\mathrm{DCM}, 0{ }^{\circ} \mathrm{C}, 9 \mathrm{~h}, \mathrm{Ar}$

$76 \%$

$E / Z: 2: 1$

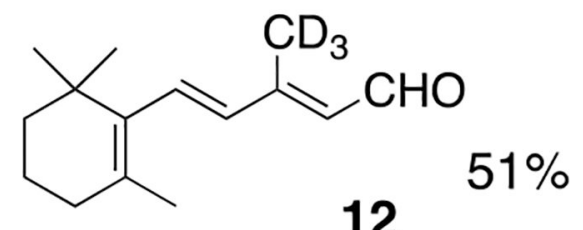

Scheme 1.

Synthesis of the $Z$ aldehyde $\mathbf{1 1}$. 


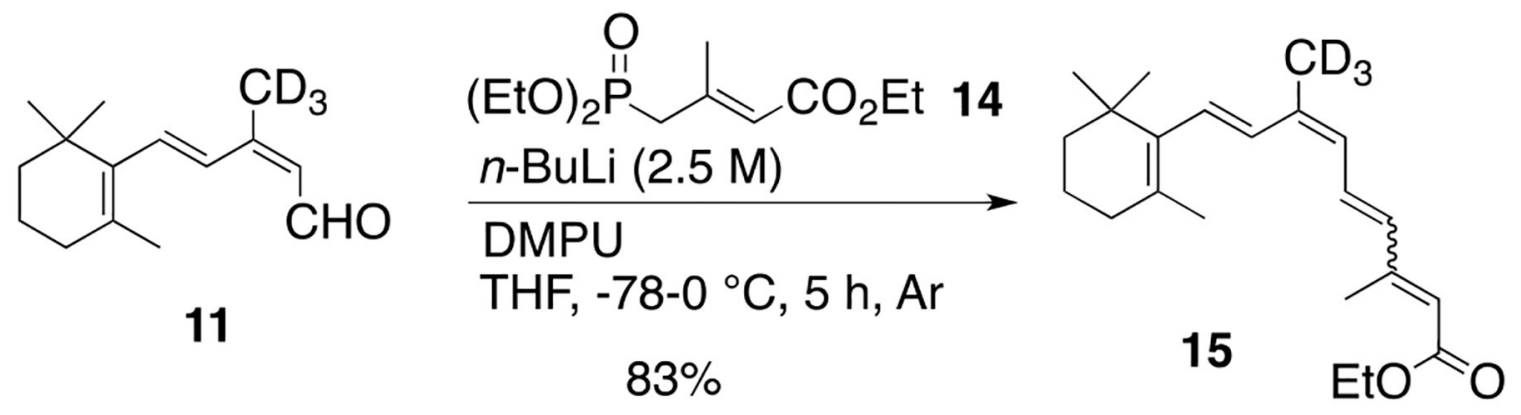

\section{$E / Z: 17: 1$}

$\underset{\operatorname{DIBAL}(1 \mathrm{M})}{\stackrel{\operatorname{DCM}, 0{ }^{\circ} \mathrm{C}, 6.5 \mathrm{~h}, \mathrm{Ar}}{\longrightarrow}}$ $92 \%$

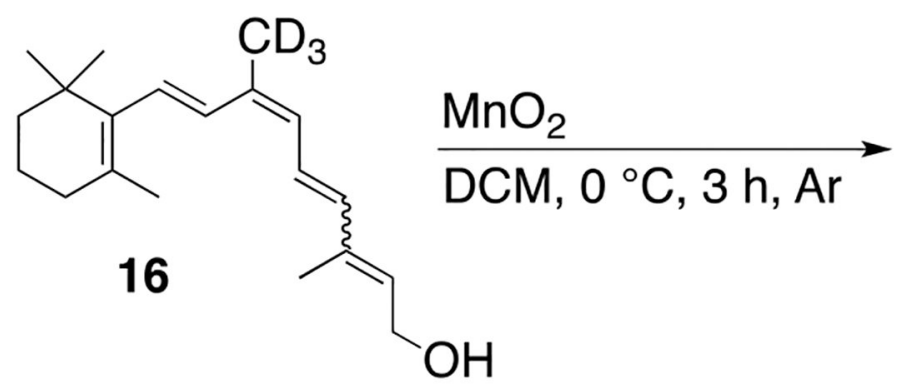<smiles>CC(C=CC=C(C)C=CC1=C(C)CCCC1(C)C)=CC=O</smiles>

17<smiles>CC1=C(/C=C/C(C)=C/C=C\C(C)=C\C=O)C(C)(C)CCC1</smiles>

18

Scheme 2.

Synthesis of $9-\mathrm{CD}_{3}-9 Z$-retinal.

$E / Z: 12: 1$ 